\title{
IMPROVING THE EFFICIENCY OF REPAIR AND CONSTRUCTION PRODUCTION IN THE REPUBLIC OF KAZAKHSTAN
}

\author{
Maxim Khan \\ Master of Technical Sciences \\ Teacher of the Department «Building materials and Technology» \\ Karaganda Technical University \\ Kazakhstan, Karaganda \\ E-mail:han_maks@mail.ru \\ Diliya Saparbekova \\ Master's student, \\ Department of «Building Materials and Technology» \\ Karaganda Technical University \\ Kazakhstan, Karaganda \\ E-mail: diliya.askarova@mail.ru
}

\section{ПОВЫШЕНИЕ ЭФФЕКТИВНОСТИ РЕМОНТНО-СТРОИТЕЛЬНОГО ПРОИЗВОДСТВА В РЕСПУБЛИКЕ КАЗАХСТАН}

\author{
Хан Максим Александрович \\ магистр технических наук, \\ преподаватель кафедры «Строительные материальы и технология» \\ Карагандинский Технический университет, \\ Республика Казахстан, г. Караганда \\ Сапарбекова Дилия Кайратовна \\ магистрант \\ кафедра «Строительные материалы и технология» \\ Карагандинский Технический университет \\ Республика Казахстан, г. Караганда
} \begin{abstract}
XXI century, is analyzed. производства, а также их значимость в XXI веке. under-repair, emergency housing. ЭФ-Энергоэффективность, недоремонт; аварийное жилье.

If we take the total amount of energy consumed in Kazakhstan, then the residential sector consumes about $50 \%$ of energy. The remaining part of the energy is directed to the transport industry, industry and other areas. In Russia and Europe, the proportion is about the same as in Kazakhstan, but the residential sector still consumes a little less energy. This is a shocking statistic. Given this information, we can say that Kazakhstan has a very low energy efficiency of buildings, primarily residential facilities. This mainly applies to residential buildings built in the $50 \mathrm{~s}$ and $70 \mathrm{~s}$.
\end{abstract}

ABSTRACT

This article discusses the issue of increasing efficiency of the repair and construction production due to energy-saving technologies. The foreign method of carrying out repair and construction production, as well as their significance in the

\section{АННОТАЦИЯ}

В данной статье рассматривается вопрос повышения эффективности ремонтно-строительного производства за счет энергосберегающих технологий. Проанализирован зарубежный метод проведения ремонтно-строительного

Keywords: MR-Major repairs, AB-Apartment building, EST-Energy-saving technologies, EF-Energy efficiency,

Ключевые слова: КР-Капитальный ремонт, МКД-Многоквартирный дом, ЭСТ-Энергосберегающие технологии,

Amendments to the Housing Code of the Republic of Kazakhstan, the addition of a whole chapter on the organization of the system of capital repairs (hereinafter KR) of common property in apartment buildings (hereinafter MCD) provided the creation of a mechanism that will reduce the amount of under-repair by increasing the repaired area of the multi-apartment housing stock. The use of modern energy-saving technologies in the course of the CD MCD will lead to a reduction in the cost of citizens to pay for housing and communal services, by improving the thermal characteristics of

Bibliographic description: Saparbekova D., Khan M. Improving the efficiency of repair and construction production in the republic of Kazakhstan // Universum: технические науки : электрон. научн. журн. 2021. 5(86). URL: https://7universum.com/ru/tech/archive/item/11748 
buildings. Modern conditions for the organization of major repairs impose new requirements for modeling repair and construction production, in terms of the mandatory use of energy-saving technologies in the course of work. The specific features of repair and construction production (hereinafter referred to as RSP) significantly complicate the application of existing methods of modeling the organization of construction in the production of repair and construction works for major repairs (hereinafter referred to as CR).

The analysis of information sources related to the problem of implementing energy-saving technologies (hereinafter referred to as ECT) during major repairs showed that the main tasks were set and solved in a fragmentary, haphazard manner, and the issues of modeling the organization of repair and construction production using energy-saving technologies were not studied or developed at all.

Along with the direct implementation of the state policy on energy efficiency, the Institute for the Development of Electric Power and Energy Conservation (IRE) oversees three important blocks of work on energy efficiency.

- The first block: creates and maintains the State Energy Register, which includes all major electricity consumers $(1,500 /+$ tons of conventional fuel per year for the industry and $100 /+$ tons of conventional fuel per year for the public sector).

- Second block: generates, manages, and selects projects for the energy efficiency map.

- The third block: conducts activities for the implementation of Step \# 59: "Attracting strategic investors in the field of energy conservation through the internationally recognized mechanism of energy service contracts" within the framework of the Plan of Nations "100 concrete steps for the implementation of five institutional reforms", announced by the first President in May 2015.

There is a significant gap in the level of scientific approach and research methods in the works devoted to solving the problems of modernization, reconstruction and major repairs of buildings, and new construction. Thus, the scientific developments of organizational and technological reliability of construction, carried out by A.A. Gusakov, S.N. Bulgakov, Yu.B. Monfred,
B.V. Prykin, P.P. Oleinik, T.N. Tsai, V.A. Afanasyev, E.M. Zavadekas and others for the conditions of new construction, have not yet found application in the field of repair and construction production. Adaptation of the obtained results to the conditions of repair and construction work can lead to fundamentally new solutions that significantly change the understanding of the process of repair and construction production. Repair and construction production (hereinafter referred to as RSP) has specific features in the design and technology of work, the organization of the production process, the use of materials (in small batches), and the limited use of high-performance equipment.

In accordance with the set goals and solved tasks, the conducted research corresponds to the following points of the specialty passport: Development of new and improvement of existing methods and forms of organization of housing, industrial, civil and other types of construction (reconstruction). Theoretical and experimental studies of the efficiency of technological processes; identification of general patterns by modeling and optimizing organizational and technological solutions. Development of principles for organizing the construction of large national economic facilities and complexes; development of flow methods, network and other construction models; improvement of calendar planning methods.

\section{Conclusion}

In accordance with the set goals and solved tasks, the conducted research corresponds to the following points of the specialty passport: Development of new and improvement of existing methods and forms of organization of housing, industrial, civil and other types of construction (reconstruction). Theoretical and experimental studies of the efficiency of technological processes; identification of general patterns by modeling and optimizing organizational and technological solutions. Development of principles for organizing the construction of large national economic facilities and complexes; development of flow methods, network and other construction models; improvement of calendar planning methods.

\section{List of literature:}

1. Alferov V.I. Applied problems of construction project management 1 V.I. Alferov [et al.]. - Voronezh: Central Chernozem Book Publishing House, 2018. - 765 p.

2. Alferov V.I. Fundamentals of scientific research on the management of construction production: lab. practicum 1. Voronezh: Scientific book, 2013. - 188 p.

3. Abramov L.I. Organization and planning of construction production Management of a construction organization: a textbook/L.I. Abramov, E.F. Manaenkova. - M.: SI, 1990. -400 p.

4. Bainev V.F. Features of determining the economic efficiency of energy consumption/ V.F. Bainev, N.F.DyudyaevMezhdunar. nauch. - prakt. conf. Mathematical methods and computers in Economics. - Penza, 2012-245c.

5. Bakushin N.V. The choice of rational technological solutions for major repairs and reconstruction of buildings: dis ... kand. tehn. nauk: 05.23.08/Bakushin Nikolay Vasilyevich. - M., 2018. - 128 p.

6. Livchak V.I. Energy saving and energy efficiency - this is the fight against wastefulness, and not the reduction of comfortable conditions: AVOK, 2010. - NQ 2.

7. Livchak V.I., Tabunshchikov Yu.A. Express-energy audit of heat consumption of residential buildings: features of conducting: Energy saving, 2019. - NQ 2. 